\begin{tabular}{l|l|l}
\hline SI & 75 & $672-674$ \\
\hline
\end{tabular}

Coconut Creek, Florida

\title{
Communicating beach management: educators; coastal engineers and local governments collaborating to create successful education programs.
}

\author{
Maggie Muurmans ${ }^{\dagger}$ Peta Leahy ${ }^{\dagger}$ Laura Richards $^{*}$ \\ ${ }^{\dagger}$ Griffith Centre for Coastal Management \\ Griffith University \\ Gold Coast, Australia
}

\author{
*City Infrastructure Assets Branch \\ City of Gold Coast \\ Gold Coast, Australia
}
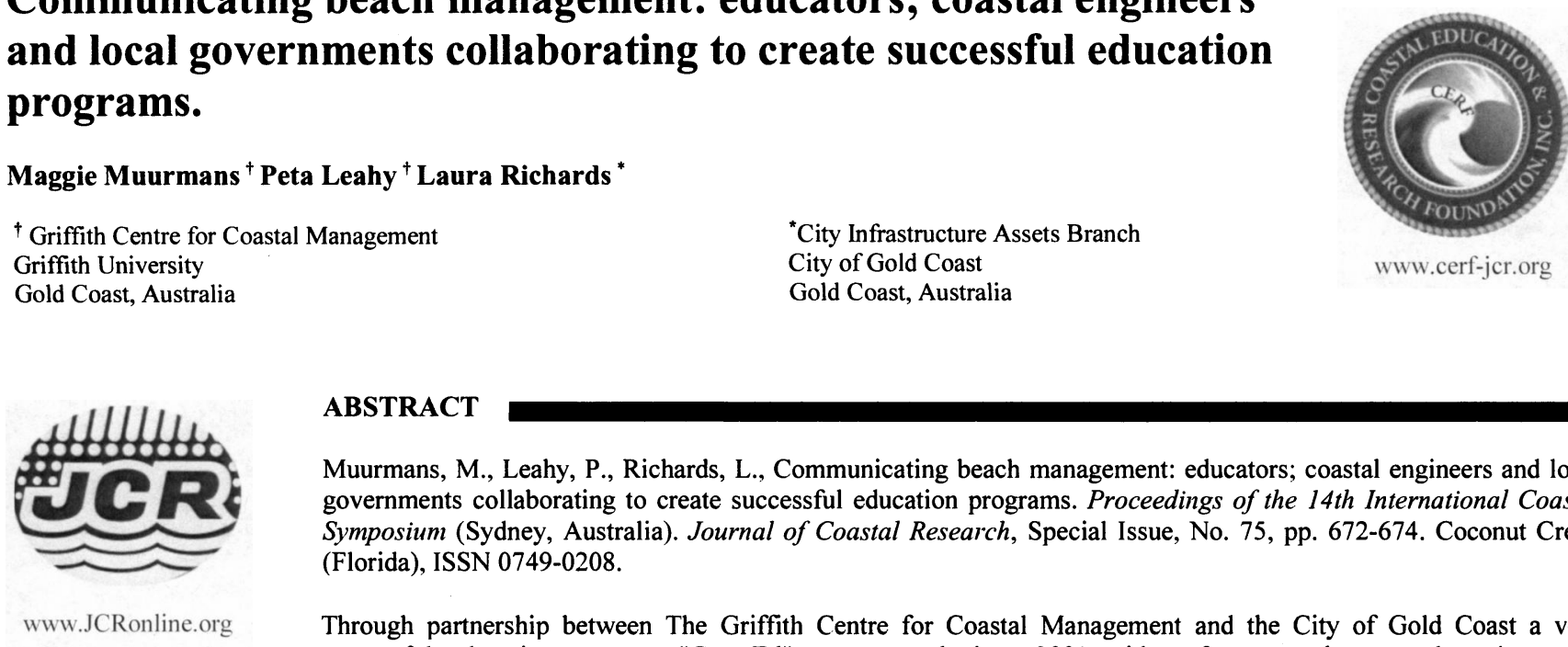

\begin{abstract}
Muurmans, M., Leahy, P., Richards, L., Communicating beach management: educators; coastal engineers and local governments collaborating to create successful education programs. Proceedings of the 14th International Coastal Symposium (Sydney, Australia). Journal of Coastal Research, Special Issue, No. 75, pp. 672-674. Coconut Creek (Florida), ISSN 0749-0208.

Through partnership between The Griffith Centre for Coastal Management and the City of Gold Coast a very successful education program "CoastEd" was created since 2001 with a focus on the coastal environment. Complimentary educational sessions are delivered to schools, community groups and residents. Topics range from beach health, coastal processes and tourism, to mangrove environments and climate change. The school programs match the Australian Curriculum and community programs are increasingly popular. The unique collaboration between a city council and a research centre has resulted in improved communication to the community as all programs are delivered by industry professionals with an extensive teaching background. The award winning program has been operational for 15 years and is highly respected in the community. CoastEd is a knowledge hub for queries the local community may have with regards to coastal protection. This paper will highlight some of the successful techniques we have used to increase awareness on certain pressing topics such as climate change, coastal protection and biodiversity.
\end{abstract}

ADDITIONAL INDEX WORDS: Beach management, partnerships, coastal and environmental education.

\section{INTRODUCTION}

Community engagement is the key towards creating environmental stewardship and raising awareness within a local community. Education provides one of the vehicles to achieve this. Research has shown that participants are subject to a range of benefits from environmental outdoor education and that these last well beyond other conventional teaching programs (Neill and Richards 1998; Neill, 2008).

CoastEd, one of the community engagement programs of the Griffith Centre for Coastal Management was established in 2001 to provide an essential service to the Gold Coast community with regards to raising awareness on the region's coastal environment, including its management, engineering structures, wildlife and habitat. The centre forms a base for some of the worlds' leading experts in coastal management and has award winning individuals delivering CoastEd's educational sessions. Over the past 15-years, the program has worked with a large number of Gold Coast and Brisbane based schools, and delivers sessions to an average of 5000 participants each year.

In response to enquiries directly from the community to the City of Gold Coast with regards to information, complaints and questions on coastal management, a partnership between the

DOI: $10.2112 / S I 75-134.1$ received 15 October 2015; accepted in revision 15 January 2015.

*Corresponding author: m.muurmans@griffith.edu.au

${ }^{\circ}$ Coastal Education and Research Foundation, Inc. 2016
Griffith Centre for Coastal Management and the City was established to assist in delivering information, education and policy on coastal issues to the community. Due to the Centre's reputation in tackling coastal management issues as well as industry professionals with teaching experience available to deliver the sessions, it is an obvious partnership.

\section{METHODS}

The ability to provide subsidised, high quality educational programs including valuable resources for teachers and communities in partnership with a local government and a renowned University, has increased the reputation for all parties involved. The City's voice through CoastEd has improved their standing with the community on coastal issues and has ensured that enquiries are being responded to in a timely and comprehensive manner.

In order to guage the perceived quality of CoastEd sessions, a survey was undertaken amongst 38 primary and secondary school teachers who have benefitted from the service. The written survey, consisting of a mix of ten multiple choice and open questions, was distributed though an on-line platform to schools from Brisbane to northern NSW after each CoastEd session. In the hope of prompting genuine responses, teachers were not required to state their names on the survey forms. Although the sessions are provided without charge, teachers were asked to provide a hypothetical monetary value to the 
sessions. This enabled CoastEd staff to make a comparison of their service with other similar services that incur a fee.

\section{RESULTS}

The results showed that although CoastEd has been operational since $2001,31 \%$ of schools were new to the program in 2014 and 2015 (Figure 4). It also demonstrated the exceptional value of the programs with $100 \%$ of the respondents interested in future CoastEd sessions and agreement that the information provided aligns well with the Australian National Curriculum. 97\% of teachers found that the sessions met their needs (Figure 1), while $73 \%$ of all teachers rated the quality of the CoastEd sessions as excellent (Figure 2). In response to the perceived monetary value of the sessions, $29 \%$ of respondent valued the service at $\$ 100$ or more (Figure 3).

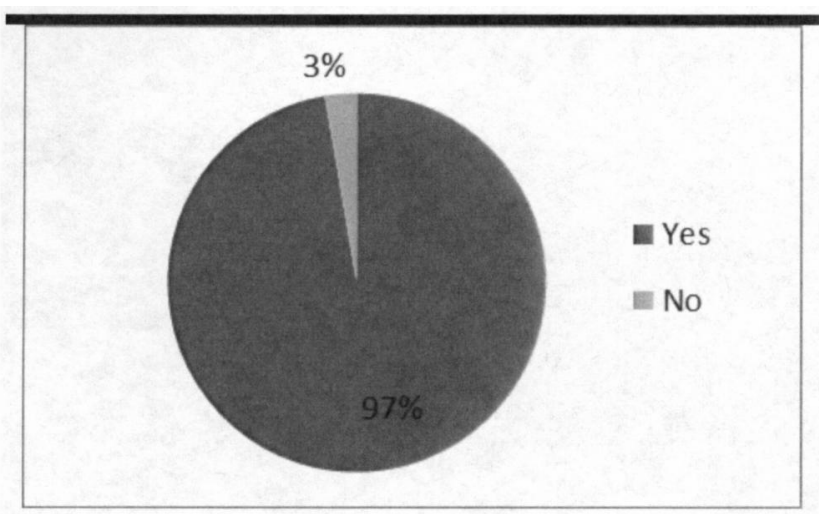

Figure 1. Did the session meet the students' and teachers' needs?

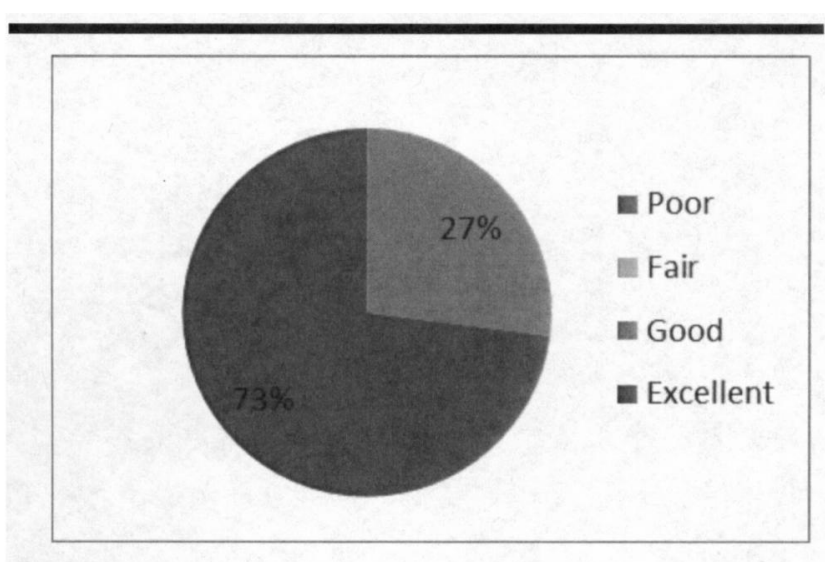

Figure 2. How the teachers valued the quality of the service.

From delivering ten sessions per year in 2001, the Centre currently has an agreement with the City of Gold Coast to provide at least 60 subsidised sessions to kindergartens, primary and secondary schools, community groups and residents. Each session runs for approximately 60 minutes. The quality of the program has increased each year and has now culminated in interactive curriculum matched programs for schools with resources for hands-on learning. The programs have been developed in collaboration with the coastal engineers based at the centre, created from recent coastal research. In 2015 the program was awarded the Australian Coastal Council's Award in the category of community engagement.

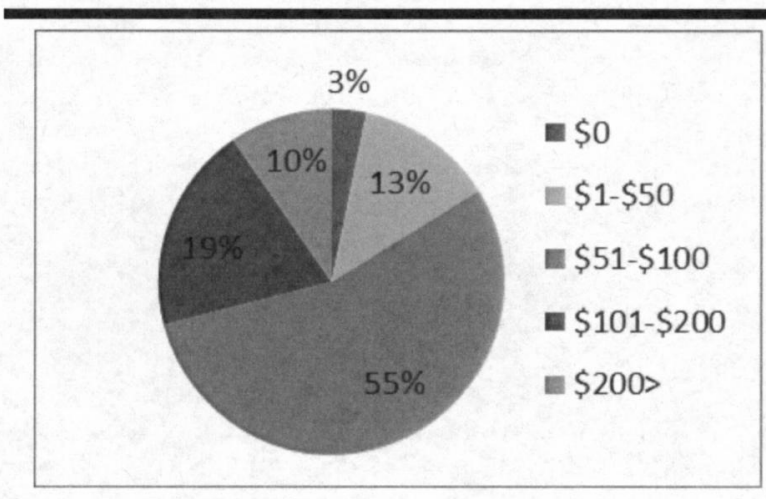

Figure 3. How the teachers valued the sessions.

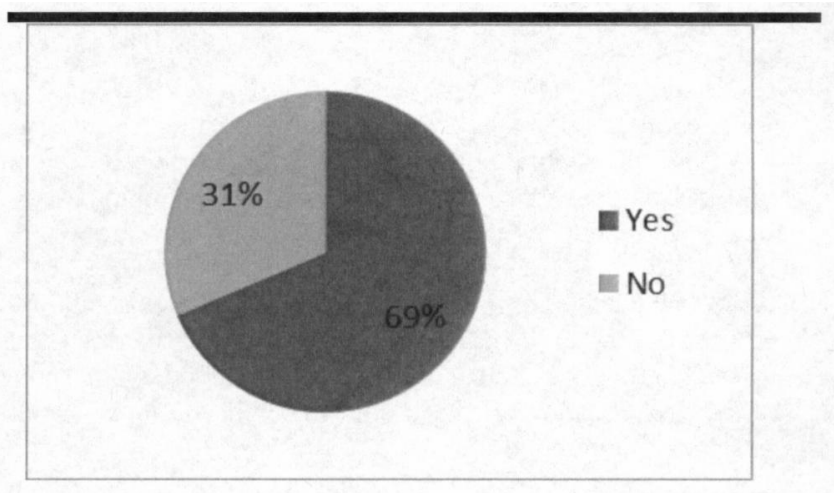

Figure 4. Did the school participate in CoastEd sessions before?

The range of programs has improved from slideshows solely on coastal processes to the current interactive, handson workshops in the field on topics ranging from beach health, tourism and geology, to mangroves, rocky shores and dunes. Participants collect primary data, complete surveys or identify biotic and abiotic processes and factors. A range of low-tech and high tech equipment is used during the sessions such as quadrats, anometers, field guides, thermometers, microscopes and identification keys. Worksheets are accompanied with lesson plans and answer sheets and all curriculum codes are posted online for each session to accommodate teachers. All programs endeavour to take all three learning styles into account including visual, auditory and kinaesthetic styles. The "Studies in Sand" program is one example of such a session using sand samples from across the world, microscopes and worksheets stimulating all learning styles.

In addition, Community education programs also have a

Journal of Coastal Research, Special Issue No. 75, 2016 
hands-on approach incorporating community projects such as BeachCare to revegetate dune ecosystems or using treasure hunts by bicycle along the coastline to learn about coastal features and coastal engineering.

\section{DISCUSSION}

Although CoastEd's educational programs in partnership with the City of Gold Coast have been running since 2001, the programs have only been matched to the Australian National Curriculum since October 2014. The above feedback from the teachers is based on sessions delivered between 2014 and 2015 . Feedback information from the years 2001-2013 have shown that teachers also rated the quality of the CoastEd sessions as good to excellent. The results of the survey, indicating the success of the CoastEd sessions, concur with other investigations into the benefits of outdoor education programs, which find that they offer a valuable means of education and training (Neill and Richards, 1998; Neill, 2008). The hands-on approach in programs such as those offered by CoastEd also raises awareness and enables individuals to make informed decisions by providing an effective introduction to real-world environmental issues (Bogner, 1998).

With the exception of research based citizen science programs that have government support such as MangroveWatch, SeagrassWatch and CoastWatch (Ferreira, 2012), CoastEd provides community programs that are solely focussed on educating the community, using national school curriculum guides, teaching about coastal issues in collaboration with the local government.

\section{CONCLUSIONS}

The Griffith Centre for Coastal Management has built a bridge between a local government body, and the community by creating programs that suit both stakeholders. This unique partnership has proven successful and will continue to deliver and expand into the future.

\section{ACKNOWLEDGMENTS}

The authors would like to acknowledge the support of the Griffith Centre for Coastal Management and Griffith University, members of the Gold Coast community, Gold Coast and Brisbane Primary and Secondary schools and BeachCare. This work has been funded and supported by the City of Gold Coast.

\section{LITERATURE CITED}

Bogner, F., 1998. The Influence of short-term outdoor ecology education on long-term variables of environmental perspective. The Journal of Environmental Education, Volume 29, No.4, 17-29.

Neill, J. and Richards, G., 1998. Does outdoor education really work? A summary of recent meta-analyses. Australian Journal of Outdoor Education, Volume 3, No.1

Neill, J, 2008. Meta-analytic research on the outcomes of outdoor education, $6^{\text {th }}$ Biennial Coalition For Education In The Outdoors Research Symposium, Bradford Woods.
Ferreira, M.A., et al., 2012. Educating citizens about their coastal environments: beach profiling in the Coastwatch project. Journal of Coastal Conservation, Planning and Management. doi:10.1007/s11852-012-0203-6) 
Communicating beach management: educators; coastal engineers and local governments collaborating to create successful education programs

Author(s): Maggie Muurmans, Peta Leahy and Laura Richards

Source: Journal of Coastal Research, Special Issue No. 75: Proceedings of the 14th

International Coastal Symposium, Sydney, 6-11 March 2016. Vol. 1 (March 2016), pp. 672-

674

Published by: Coastal Education \& Research Foundation, Inc.

Stable URL: http://www.jstor.org/stable/43752640

Accessed: 12-10-2016 04:48 UTC

JSTOR is a not-for-profit service that helps scholars, researchers, and students discover, use, and build upon a wide range of content in a trusted digital archive. We use information technology and tools to increase productivity and facilitate new forms of scholarship. For more information about JSTOR, please contact support@jstor.org.

Your use of the JSTOR archive indicates your acceptance of the Terms \& Conditions of Use, available at http://about.jstor.org/terms

Coastal Education \& Research Foundation, Inc. is collaborating with JSTOR to digitize, preserve and extend access to Journal of Coastal Research 